University of East London Institutional Repository: http://roar.uel.ac.uk

This paper is made available online in accordance with publisher policies. Please scroll down to view the document itself. Please refer to the repository record for this item and our policy information available from the repository home page for further information.

Author(s): Rogers, P.; Webb, Geoffrey P.

Title: Estimation of body fat in normal and obese mice

Year of publication: 1980

Citation: Rogers, P.; Webb, G.P. (1980) 'Estimation of body fat in normal and obese mice' British Journal of Nutrition 43 (1) 83-86

Link to published version: http://dx.doi.org/10.1079/BJN19800066

DOI: 10.1079/BJN19800066 


\title{
Estimation of body fat in normal and obese mice
}

\author{
BY P. ROGERS AND G. P. WEBB \\ Department of Paramedical Sciences, North East London Polytechnic, \\ Romford Road, London EI $54 L Z$ \\ (Received 2 May 1979 - Accepted 4 August 1979)
}

1. Lee Index (weight $\left(\mathrm{g}^{0.33}\right) \div$ nasoanal length $(\mathrm{mm})$ ), density, body water and proportional weight of the gonadal fat pad were tested as estimates of body fat in a normal population of mice and a population which included obese mice.

2. In a normal population only body water and fat-pad weight correlated significantly with body fat.

3. In a population of normal and obese mice all four indices correlated significantly with body fat.

4. Lee Index had little advantage over weight: length as an estimate of body fat, and density did not correlate well enough to be used as a method of estimation.

5. Proportional weight of the gonadal fat pad is recommended as a simple reliable estimate of body fat in normal or obese mice.

There is at present an enormous interest in the mechanisms which serve to regulate food intake and lipid deposition and thus the causes and effects of obesity. There are a number of animal models of obesity which are the subject of intensive study; in rodents obesity may be induced by chemical agents such as gold thioglucose (GTG; Brecher \& Waxler, I949) and bipiperidyl mustard (BPM ; Rutman et al. 1966), by providing pleasant-tasting food or sugar solutions (Kanarek \& Hirsch, I 977) or by genetic inheritance as in the ob/ob mouse and Zucker fatty rat (Bray \& York, I971). However, obesity as defined by an excessive accumulation of fat (Davidson et al. 1975) is not always associated with a high bodyweight (Larsson, 1967; Rogers et al. 1979) and therefore an objective measure of adiposity should always be used as the criterion for obesity. Direct measurement of body fat in the mouse involves drying and extraction procedures which are not only time-consuming but also destructive, precluding for example histological examination of organs. We now report experiments in which a number of methods of indicating obesity are assessed to determine whether they are reliable indices of obesity and also whether they are sensitive enough to give an accurate estimate of the body fat content of normal mice which have a comparatively narrow range of body fat contents. Preliminary results on a normal population have previously been communicated (Webb \& Rogers, 1979).

\section{MATERIALS AND METHODS}

A total of 170 Theiller's Original (T/O) mice of both sexes were used in this study. Approximately half the animals were not given any treatment and thus represent a normal population; the remaining animals were made obese by intraperitoneal injections of either GTG (up to $0.6 \mathrm{mg} / \mathrm{g}$ body-weight) or BPM cyclized in borate buffer $\mathrm{pH} 9$ (up to $0.025 \mathrm{mg} / \mathrm{g}$ ).

The animals were killed by diethyl ether suffocation, weighed, their nasoanal lengths determined and Lee Index calculated using the formula weight $\left(\mathrm{g}^{0.33}\right) \div$ nasoanal length $(\mathrm{mm})$. For density measurements volume was obtained by water displacement or by measuring the weight when fully immersed in water (the animals were thoroughly wetted prior to immersion to remove air trapped in the fur and attached to a heavy metal bar). The right gonadal fat pad was carefully dissected out and weighed and the whole carcass was then dried to constant weight in an oven at $105^{\circ}$. Whole body fat was measured by Soxhlet extraction of the dried carcass to constant weight using carbon tetrachloride as solvent. 
Table I. The correlations between percentage body fat and body-weight, Lee Index (weight $\left(\mathrm{g}^{0.33}\right) \div$ nasoanal length $\left.(\mathrm{mm})\right)$, proportional weight of the gonadal-fat-pad, density and percentage body water, for a population of thirty-two male and fifteen female Theiller's Original mice

(Where no significant correlation was found only the correlation for the total population is given and when there was no significant difference between the regression lines for the two sexes only the total equation is given)

\begin{tabular}{|c|c|c|c|c|c|}
\hline Method & & $\begin{array}{l}\text { rrelation with } \\
\text { entage body fat }\end{array}$ & $\begin{array}{l}\text { Statistical significance } \\
t \quad \text { of correlation }\end{array}$ & Equation & $\begin{array}{l}\text { Standard erro } \\
\text { of regression }\end{array}$ \\
\hline $\begin{array}{l}\text { Body-wt } \\
\text { Lee Index } \\
\text { Density } \\
\text { Proportional } \\
\text { gonadal-fat-pad wt } \\
\quad \text { Total }\end{array}$ & 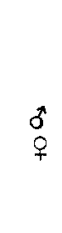 & $\begin{array}{l}0.13 \\
0.08 \\
0.12 \\
0.82 \\
0.96 \\
0.87\end{array}$ & $\begin{array}{l}\text { NS } \\
\text { NS } \\
\text { NS } \\
- \\
P \overline{-} 0.001\end{array}$ & $\begin{array}{c}\bar{Z} \\
\overline{-} \\
y=-0 \\
-0.000947 x+ \\
-0.00157\end{array}$ & $\begin{array}{c}\bar{Z} \\
\bar{Z} \\
8 \cdot 11 \times 10^{-5}\end{array}$ \\
\hline $\begin{array}{l}\text { Percentage } \\
\text { body water } \\
\text { Total }\end{array}$ & $\begin{array}{l}0 \\
+ \\
+\end{array}$ & $\begin{array}{l}-0.87 \\
-0.99 \\
-0.92\end{array}$ & $p \overline{-}$ & $\frac{-}{y=-0.797 x+75.2}$ & $\frac{\bar{Z}}{5.21 \times 10^{-2}}$ \\
\hline
\end{tabular}

NS, not significant.

\section{RESULTS}

(a) Estimation of total body fat in a normal population. When correlations were made between total body fat and Lee Index, density, as measured by displacement, or percentage gonadalfat-pad weight, the only significant correlation $(P<0.001)$ was between the proportional gonadal-fat-pad weight and total body fat (Table 1). The slope and position of the regression lines relating percentage gonadal-fat-pad weight to total body fat were not significantly different in the two sexes. There was no significant correlation between bodyweight and percentage body fat in normal, untreated mice $(r 0.13)$. There was however a high negative correlation between body water and body fat $(r-0.91)$ and also between percentage fat-pad weight $(y)$ and body water $(x)(r-0.87, y=-739 \cdot 96 x+73 \cdot 6)$.

In a separate sample of twelve normal animals, in addition to measuring density by volume displacement it was also measured by weighing the mice in air and water. The two methods gave a high correlation $(r 0.86)$ with each other but neither correlated significantly with the proportional weight of the gonadal fat pad $(r 0.30$ displacement, $r-0.0$ I relative weight).

(b) Estimation of body fat in a population including treated animals with varying extents of obesity. A separate sample of eighty-one mice, including animals made obese with GTG and BPM was used for this experiment. The range of fatness $(\%)$ between 3 and 48 and of body-weight $(g)$ between 20 and 69 ensured that with all the methods of estimation tested there was a significant correlation between the index and the percentage body fat (Table 2).

As expected, the best correlation was between percentage body water and body fat $(r-0.997)$; neither the slopes nor the intercepts were significantly different for the two sexes. The fat pad relationships with total fat were also not significantly different in male and female and again they gave a high correlation with total body fat ( $\mathrm{r} 0.97$ ).

The regression lines of Lee Index $v$. total body fat in the two sexes were significantly different in position $(P<0.001)$ although the slopes were not significantly different. The Lee Index correlated highly with body fat in each instance ( $r 0.76$ male, $r 0.94$ female): the correlation for the female mice was only slightly better than the correlation between bodyweight and total body fat and for male mice was slightly worse. Furthermore the correlation 
Table 2. The correlations between percentage body fat and body-weight $(g)$, Lee Index (weight $\left(\mathrm{g}^{0.33}\right) \div$ nasoanal length $\left.(\mathrm{mm})\right)$, proportional weight of the gonadal-fat-pad, weight: length and percentage body water, for a population of thirty-four male and forty-seven female Theiller's Original mice (seventeen untreated, twenty-nine treated with bipiperidyl mustard and thirty-five treated with gold thioglucose)

(When there was no significant difference between the regression lines for the two sexes only the total equation is given)

\begin{tabular}{|c|c|c|c|c|c|}
\hline \multicolumn{2}{|c|}{ Method } & \multicolumn{2}{|r|}{$\begin{array}{l}\text { Correlation with } \\
\text { percentage body fat* }\end{array}$} & Equation & \multirow{2}{*}{$\begin{array}{c}\text { Standard error } \\
\text { regression } \\
1 \cdot 11 \times 10^{-1} \\
5.01 \times 10^{-2}\end{array}$} \\
\hline $\begin{array}{c}\text { Body wt } \\
\text { Total }\end{array}$ & $\begin{array}{l}0 \\
+ \\
+\end{array}$ & & $\begin{array}{l}0.83 \\
0.91 \\
0.80\end{array}$ & $\begin{array}{l}y=0.92 x+26.9 \\
y=0.76 x+21 \cdot 4\end{array}$ & \\
\hline $\begin{array}{l}\text { Wt: length } \\
\text { Total }\end{array}$ & $\begin{array}{l}0 \\
+ \\
+\end{array}$ & & $\begin{array}{l}0.84 \\
0.93 \\
0.82\end{array}$ & $\begin{array}{l}y=0.0075 x+2.65 \\
y=0.0067 x+2.11\end{array}$ & $\begin{array}{l}8.67 \times 10^{-4} \\
4.01 \times 10^{-4}\end{array}$ \\
\hline $\begin{array}{l}\text { Lee Index } \\
\text { Total }\end{array}$ & $\begin{array}{l}d \\
q\end{array}$ & & $\begin{array}{l}0.76 \\
0.94 \\
0.83\end{array}$ & $\begin{array}{l}y=0.00015 x+0.296 \\
y=0.00016 x+0.279\end{array}$ & $\begin{array}{l}2.30 \times 10^{-6} \\
9.15 \times 10^{-6}\end{array}$ \\
\hline $\begin{array}{l}\text { Proportiona } \\
\text { Total }\end{array}$ & d-fat-pad wt & $\begin{array}{l}\delta \\
\vdots \\
+\end{array}$ & $\begin{array}{l}0.97 \\
0.96 \\
0.97\end{array}$ & $y=0.000979 x+-0.00130$ & $2.95 x \times 10^{-5}$ \\
\hline $\begin{array}{l}\text { Percentage } \\
\text { Total }\end{array}$ & & $\begin{array}{l}\delta \\
\stackrel{+}{*}\end{array}$ & $\begin{array}{l}-0.996 \\
-0.997 \\
-0.997\end{array}$ & $y=-0.72 x+73 \cdot 72$ & $6.27 \times 10^{-8}$ \\
\hline
\end{tabular}

- All correlation coefficients significant $P<0.001$.

between weight: length and total fat was very similar to that between Lee Index and total fat. In a separate sample of forty-two mice, in which half were treated with GTG or BPM, there was a significant negative correlation between density measured by the relative weight in water and air and the proportional weight of the gonadal fat pad $(r-0.52, P<0.001)$.

\section{DISCUSSION}

It is clear from these results that only body water measurements and proportional weight of the gonadal fat pad are reliable estimates of total body fat in normal T/O mice. Bodywater measurement has little advantage over direct fat measurement in terms of time and destruction of the carcass. Proportional weight of the gonadal fat pad gives a high correlation $(r 0.87)$ with total body fat as measured by extraction even within the comparatively narrow range of fatness $(\%)$ encountered in the normal sample (3-13). The strength of the association can be ascertained from the square of the regression coefficient $(0 \cdot 76)$. Thus $76 \%$ of the variation in fat-pad weight can be explained by a linear regression with body fat.

When the sample included obese animals, the Lee Index correlated very significantly $(P<0.00 \mathrm{I})$ with body fat and although it was not as accurate an estimate as the weight of the gonadal fat pad (and the relationship between the two sexes was different), it has the important advantage that it can be measured in a living animal. If the Lee Index is, however, compared with a simple weight:length ratio there is no apparent advantage in calculating the Lee Index and there is little advantage in the Lee Index as compared to body-weight only. Bernardis \& Patterson (1968) showed that the Lee Index correlated significantly with body fat content in obese rats but they did not compare it with a simple weight:length 
ratio. The original author (Lee, I928) derived this formula for rodents from a nutritive index for children (Von Pirquet, 1917), though he did not measure fatness of his rats but simply made a subjective assessment of the nutritive state of the animal. Despite this, the Lee Index is still used as an index of obesity in rodents (e.g. Bunyan et al. 1976). The highly significant $(P<0.00 \mathrm{I})$ but low correlation $(r-0.52)$ between density and proportional weight of the gonadal fat pad confirms that density does decline as adiposity increases. However, this measure of adiposity in the mouse would appear to have little practical value particularly as the animals have to be killed before immersion for density measurement.

Estimation of total fat by weight of the gonadal fat pad has the advantages of speed and simplicity and the relationship for the two sexes in T/O mice is not significantly different; the relationship is also not significantly different when the animals are from a normal, GTG-obese or BPM-obese population. This is, therefore, the method we have adopted for body fat estimation in our laboratory whenever direct determinations are inappropriate.

The authors gratefully acknowledge a generous supply of gold thioglucose from the Schering Corporation, Bloomfield, New Jersey, and the useful advice of Dr M. Jacobson, Department of Biology, North East London Polytechnic.

\section{REFERENCES}

Bernardis, L. L. \& Patterson, B. D. (1968). J. Endocr. 40, 527.

Bray, G. A. \& York, D. A. (1971). Physiol. Rev. 51, 598.

Brecher, J. R. \& Waxler, S. H. (1949). Proc. Soc. exp. Biol. Med. 70, 498.

Bunyan, J., Murrel, E. A. \& Shah, P. P. (1976). Br. J. Nutr. 35, 25.

Davidson, S., Passmore, R., Brock, J. F. \& Truswell, A. S. (1975). Human Nutrition and Dietetics, 6 th ed. Edinburgh: Churchill Livingstone.

Kanarek, R. B. \& Hirsch, E. (1977). Fedn Proc. Fedn Am. Socs exp. Biol. 36, I 54.

Larsson, S. (1967). Acta Physiol. scand. Suppl. 294, 42.

Lee, M. O. (1928). Am. J. Physiol. 89, 24.

Rogers, P. D., Webb, G. P. \& Jagot, S. A. (1979). I.R.C.S. Med. Sci. 7, 402.

Rutman, R. J., Lewis, F. S. \& Bloomer, W. D. (1966). Science, N.Y. 153, 1000.

Von Pirquet, C. P. (1917). System der Ernahrung, vol. 1. Berlin: Julius Springer.

Webb, G. P. \& Rogers, P. D. (1979). Proc. Nutr. Soc. 38, 75A. 